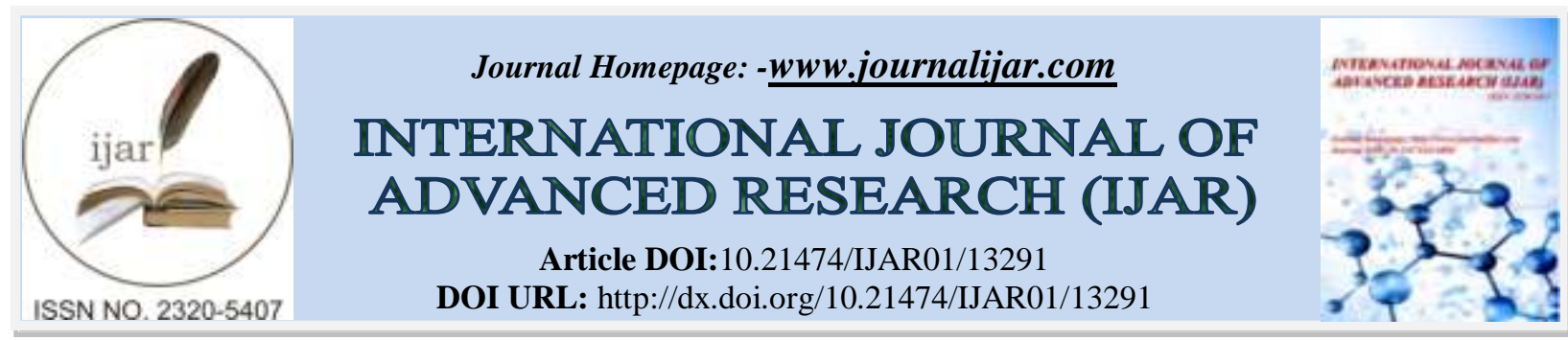

RESEARCH ARTICLE

\title{
CHILDREN'S EVIDENCE IN CUSTODY DISPUTES CASES IN THE SHARIA COURTS
}

Zaini Nasohah ${ }^{1}$, Wafaa Yusof ${ }^{1}$, Zuliza Mohd Kusrin ${ }^{1}$, Muhammad Nazir Alias ${ }^{1}$ and Abu Suffian Abu Yaziz

1. Centre of Sharia Reseach, Faculty of Islamic Studies, Universiti Kebangsaan Malaysia, Bangi, Selangor, Malaysia.

2. Department of Sharia Judiciary Malaysia.

\section{Manuscript Info}

.........................

Manuscript History

Received: 15 June 2021

Final Accepted: 19 July 2021

Published: August 2021

Key words:-

Children's, Children's Evidence,

Children's Right, Custody Dispute

Cases, Sharia Court

\section{Abstract}

In the process of trial in court, evidence disclosure is essential to uphold justice. Basically, every party is qualified to provide evidence before the judge decides. In the case of child custody disputes, besides the statements by the mother and the father, statements from the child involved can help the court in making the right decision. According to Islamic law, children who have attained the age of mumayyiz can be given the opportunity to choose. In addition, their views can also be taken as a support evidence to help the court make a decision. This article will analyse children's rights to express their views, particularly in the determination of child custody disputes. The debate also looks at current legal provisions and practices in the Sharia Court. The analysis found that judges' approach in accepting children's evidence varies. There are still no specific procedures that can be used as a guide by the Sharia Court. The differences include the methods of interviewing or taking recorded statements, the procedures applied and the location where statements are recorded.

Copy Right, IJAR, 2021,. All rights reserved.

\section{Introduction:-}

In general, every person who meets the conditions is eligible to be taken evidence from in order to enable the judge to make a decision. An evidence is also the basis of the smoothness of a trial (Amin al-Jarumi 2005). This issue of law of evidence has been discussed by Islamic jurists with many debates on testimonies and evidence from adults. The issue of child's evidence is a matter that should not be neglected as it requires solutions and answers. Children are also individuals who have the right to defend themselves or to get justice, whether for themselves or other parties (Roslina 2014). In the case of determining child custody in particular, evidence from the child involved can help the court to make more accurate decisions. Even more so in determining child custody, their welfare aspect needs to be prioritised. However, in the trial practice in courts, children's evidence are not always taken in all cases whether in the trial case. Similarly in the cases resolved by mutual agreement between the parents involved. This can raise the question of whether the child's rights have been granted.

\section{Methodology:-}

This article is a qualitative study through content analysis. The data are derived from the debate of Islamic jurists in main fiqh books and related statutes. The data are descriptively and comparatively analysed with discussions 
focusing on definitions and scope of evidence. The analysis is also focused on reasons for the appropriateness of children to be taken evidence from in a trial of custody case in the Sharia Court.

\section{Findings and Discussion:- \\ Evidence}

At its principle, evidence is the methods used to prove a fact. This fact is what determines whether or not there is any right or liability in civil and criminal cases. Fact that has been successfully determined of its existence is considered as proven and so is the opposite. Evidence and proof, are two different terms despite having very close connection (Ruzman 2007).

Evidence in Islam is often associated with the term al-bayyinah (Mahmud Saedon 1995). In general, al-bayyinah encompasses all forms of evidence adopted in the court. In terms of language, the word al-bayyinah also means dalil (proof) or hujjah (argument). In terms of terminology, the word al-bayyinah has a similar meaning as evidence (alFaruqi 1995). According to al-Asfahaniy, al-bayyinah is a clear indicator of whether it is logically sensible or even known through senses. Ibn Qayyim (1995) explains, al-bayyinah is the name for everything that can explain and show the truth. Ibn Qayyim (1995) and Ibn Farhun (2001) further describe, there are some terms referring to the same meaning as al-bayyinah which are al-hujjah, al-dalil, al-burhan, al-ayat, al-tabsirat, al-alamat and alammarat (Ruzman 2008). The word al-bayyinah is general and it covers all forms of evidence used to prove the truth of a subject including testimony, pledge, oath and qarinah.

Besides al-bayyinah, the word al-shahadah (testimony) also has a very close relation with the purpose of the meaning of evidence according to Islamic law. Discussions on both are inseparable and interconnected. The Islamic jurists have disagreed in defining the meaning of bayyinah, whether it is in line with shahadah or the opposite.

The first opinion; some Islamic jurists state that the concept of al-bayyinah and al-shahadah are similar. This is based on the other terms used to refer to both of these concepts which are burhan, dilalah, ayat, tabsirat, alamah and ammarah that have almost the same meaning (Ibn Qayyim 1995). This is further supported by the word of Allah SWT in verse 24 Surah an-Nur which uses the word al-shahadah to refer to the meaning of al-bayyinah.

Apart from this Quranic verse, there are hadiths of the Prophet PBUH that use the word al-bayyinah which means al-syahadah. For example in the hadith of Anas bin Malik which means (al San'ani 2000):

"The first $l i$ 'an in Islam was when Hilal bin Umayyah accused his wife of committing adultery with Syuraikh bin Samha. The Prophet PBUH said to Hilal: Bring forward al-bayyinah (witness) or otherwise, hadd punishment (because of qazaf) will be imposed on your back."

This hadith is about the law of $l i$ 'an which is an oath procedure performed in the case of a husband accusing his wife of committing adultery despite him not having four male witnesses. The word al-bayyinah in this hadith refers to alshahadah, witnesses of four men.

The second opinion; al-bayyinah carries a general definition that covers all forms of evidence that can lead to truth and justice. This opinion was presented by Ibn al-Qayyim (1995) in his book al-Turuq al-Hukmiyyah Fi al-Siyasah al-Shar'iyyah.

"Al-bayyinah is the name for everything that can explain and show the truth. Anyone who only restricts the meaning of bayyinah as two witnesses, four witnesses or one witness will not achieve the true meaning of the word bayyinah. Al-bayyinah in the Quran does not only mean two witnesses, it means argument, guidance or principle of justice. The Prophet PBUH said:"Al-bayyinah (evidence) on the one who claims and oath on the who denies it. This hadith implies that anyone who makes a claim must bring forward any evidence that can support his claim and the evidence of two witnesses is one of bayyinah.

It is undeniable that there are other evidence stronger than witness testimony. For example, evidence of circumstances favoring the claimant. It is stronger than witness testimony. The words al-burhan, al-ayat, al-tabsirat, al-alamat and al-amarat have the same meaning as al-bayyinah. Furthermore, if we look into the basis of Islamic law, we will find that it recognises all of these elements as the basis of judgment (Ibn Qayyim 1995). 
According to al-Hurri, al-shahadah and al-bayyinah carry different meaning. In fact, al-shahadah is part of the albayyinah concept because al-bayyinah is a comprehensive proof that explains the truth of a fact.

Apart from that, the Islamic jurists argument that holds this second opinion also describes the word al-bayyinah in the Quran does not only mean al-shahadah (testimony) but it means a clear argument, evidence or dalil. It can be seen as an example in Surah al-Ankabut verse 5, Surah al-An'am verse 57 and Surah al-Hadid verse 2.

This second opinion is well-suited to today's social development and public interest. It is in line with the nature and spirit of Islamic law. In fact, there are other forms of evidence that are stronger than a testimony which is circumstantial evidence. It is more convincing than the testimony of a male witness. This second opinion is also a reference and is accepted by the Sharia Courts in Malaysia. In other words, shahadah is different from bayyinah. Shahadah is one of the forms of bayyinah.

Taking this approach into account, some issues related to the needs and claims found in the concept of al-shahadah can be solved. These issues include a child's evidence in the interest of his parents as well as the evidence of a child who has not reached puberty (Ruzman 2007). Even though their evidence do not meet the claims and conditions of the al-syahadah concept but are still acceptable based on the principle of al-bayyinah. It is up to the court to determine the position and strength of the evidence.

\section{Child's Ability To Provide Evidence}

Children means little boys or girls. This term commonly refers to a category of children who are under seven or eight years old. Whereas according to the Children Act 2001 (Act 611), children are those under 18 years of age.

In terms of Islamic jurisprudence, the terms children often used in fiqh books are sabiyy, ghulam and saghir for boys, and sabiyyah, jariyah and saghirah for girls. These words show their nature or physiology as sighar (small) or sighar al-sinn (young age) or siba (young or small).

Children are individuals with physiological nature or state that have not yet completed the growth of their human ability, namely physical growth and intellectual ability. The growth process towards maturity takes different amount of time between different individuals. In the growth process towards maturity, children will pass through two stages of physiological growth. The Islamic jurists will differentiate these two stages based on the tamyiz characteristics reached by the children during their growth.

Tamyiz in terms of language means the ability to differentiate something. In terms of fiqh term, there are various opinions among the Islamic jurists who try to elaborate the meaning of tamyiz by describing the features of a mumayyiz child. Among them are those who can eat, drink and wash by themselves without the help of others. Some describe its meaning with the ability to understand questions and can answer them (Alwi 1999).

According to Abu Zahrah (1986), the Islamic jurists explain that the meaning of tamyiz is the ability to generally understand the effects of a sale and purchase contract. From this explanation, it can be concluded that tamyiz as according to fiqh is the ability to understand conversation, to identify something, to fulfill personal needs alone without the help of others and to distinguish between good and evil.

According to medical experts, during the maturation process, each child will go through two stages of development.

\section{Pre-mumayyiz stage}

This stage begins once a child is born until his or her age is nearly seven years old. Children do not have tamyiz characteristics at this stage.

\section{Mumayyiz stage}

This stage begins when a child is seven years old. From that age, children already have tamyiz characteristics. The Islamic jurists state that the minimum age of tamyiz is seven years old. This stage will continue until the tamyiz characteristics are completed, which is when the child hits puberty. Tamyiz characteristics begin in an imperfect form and will become more perfect when a child hits puberty. Therefore, the maximum age for tamyiz is the age of puberty. The tamyiz used for children does not mean that the mind is perfect, but merely able to think and distinguish between good and bad things. 
In summary, tamyiz is not a criterion that differentiates children and adults, but it is just a criterion that differentiates between two childhood stages of children who have yet to become mumayyiz and mumayyiz children. While the criterion that distinguishes between children and adults is bulugh which means having attained the age of puberty. Therefore, a child is an individual who has not reached puberty and an adult is an individual who has reached puberty.

This means that in terms of fiqh, the definition of a child is not solely bound by age or physical size of either big or small the child is. The main thing to measure is their level of intelligence. In the context of the basic question of whether or not child's evidence is acceptable is by evaluating whether the child is able to distinguish between good things and bad things or not.

\section{Child's Evidence in Sharia Law of Evidence in Malaysia}

Contrary to civil court system (Aminuddin \& Siti Nurul Aziera 2012), to this day there is no specific statute used as a reference by the Sharia Court pertaining to child's evidence. The only provision currently used by the Sharia Court which covers all types of evidence is the Sharia Court Evidence Act or Enactment. This law has been passed in every state. Due to the absence of specific guidelines and procedures for the application of child's evidence in the Sharia Court, the wisdom of the Judge is crucial in determining the procedures and methods of obtaining evidence from them.

Based on the Islamic law of evidence discussed by the Islamic jurists, children cannot be witnesses. However, children's evidence can be taken as bayyinah (regular evidence). Therefore, children's evidence may actually be used as evidence of support for adults' testimonies. In fact, the evidence of this group may help the court in the absence of any other strong evidence.

Based on the act and enactment, Section 83 (4) of the Sharia Court Evidence (Federal Territories) Act 1997 (Act 561) for example has provided that a person who has not reached puberty or a person with mental disability is competent to give bayyinah but is not competent to give shahadah.

It is evident that through this provision, sharia law in Malaysia accepts the principle of bayyinah as one of the means of proof. Since matters regarding Islamic affairs are state's jurisdiction, thus each state has its own sharia evidence enactment. However, the content of each provision is similar. The acception of bayyinah can solve many problems. This means that the bayyinah (evidence) of a fasiq (impious) person, a child or a person who is not strong in memory can be accepted.

In reality, evidence that is regarded as bayyinah has a very wide scope of use. For example, evidence from a child is considered as bayyinah. Similarly with evidence that is provided by a non-Muslim as well as an expert witness. The evidence from this group does not require an oath. This means that the evidence they provide is not binding on the court. It is merely as a guide for the Judge to make a decision on a case (Muhammad Abdul Karim 2015).

In the case of hadanah in the Sharia Court, it is a process for a child to make a choice between his father or his mother or the parties claiming such custody. The child's evidence taken is very important to ensure his welfare and future.

In addition, for the provision of the law on child's evidence, in cases involving a child and his parents, has been provided through Section 85 (2) of the Sharia Court Evidence Act:

Evidence of a child against his parent and that of parent against his child is admissible as shahadah and bayyinah.

Whereas Section 85 (4) provides for:

Evidence of a parent for his child and that of a child for his parent is admissible as bayyinah.

In Section 85 (2) above, the meaning of 'against' his parents is the evidence given by a child to oppose these parties. Meanwhile, the word 'for' in Section 85 (4) is a description of a child given to support his parents.

Based on both of the above provisions, it is clear that every evidence given by a child against or even for his parents is accepted as bayyinah, rather than shahadah. Therefore, it is up to the Sharia Court judge to consider whether to 
accept the evidence or not. In determining whether the evidence of a child is acceptable or otherwise, the Judge needs to exercise his own discretion. The judge needs to determine whether the individual brought before him is a child who has not attained mumayyiz, a child who is mumayyiz but not yet become baligh or a child who has become baligh (puberty).

\section{The Rights of Children to Give Views and Evidence in Determining Custody}

Islam does not prevent children from giving good opinions or views. Children's views should be respected as long as they do not lead to any damage or harm (Adnan 1989). In a discussion under Islamic law, the children's views are often connected with the determination of custody. However, Islamic law limits a certain age in allowing children to give their views. In addition, the views of the Islamic jurists in this regard also vary.

According to the views of Shafie and Hanbali schools of thought, a child is generally given the right to make a choice. The choice of a child to live with either the mother or the father can be assumed that the elected person loves the child more (Zanariah 2010). However, according to the Hanbali school, only seven-year-olds are eligible to be given the right to choose their guardian. At this age, children usually already know how to distinguish between good and bad. As for girls, the more entitled to care for them is the father. According to Hanbali school, daughters need care from the father more (Ibn Qudamah 1993). Whereas for the views of Hanafi and Maliki schools, children should not be given the right to choose their guardians. The argument of the Hanafi school, children will usually choose the one that may harm them. Children will usually choose the person who does not educate them and never stops them from what they want (al Kasani 1997). Imam Malik explains on this issue, children are unable to speak for themselves and have no idea of their own destiny (al Shankiti 2004).

In the meantime, even though the Hanbali school allows children to make a choice but it set forth two conditions to allow a child to be given the choice to choose his guardian. First, the elected guardian shall be someone who is qualified to be a guardian according to the Islamic law. Second, the child is not intellectually deficient. If a child is intellectually deficient, he should be handed over to the mother. According to this view, the most deserving person to care for an intellectually deficient child is his mother even though the child has reached puberty (Ibn Qudamah 1983). Therefore, the role of the judge is very important to examine and determine the matters stated above are met. Among them is firstly; whether the child has become clever and secondly; whether or not the choice of the child will cause harm. It is in this process of identifying options that the collection of evidence takes place. In cases of child custody, the judge does not necessarily follow the child's choice. Instead, what is more important is that the welfare of the child will be guaranteed.

This means that the selection of guardian done by a mumayyiz child is not absolute. The court in making judgments should take into account whether such selection will negatively affect the child's welfare (Zanariah 2010 ). Therefore, all forms of evidence of the children who are qualified to testify are important to the court in making the right decision. In the context of the Sharia Court in Malaysia, the Sharia evidence law does not prevent the court from taking the evidence from eligible children. Eligibility is determined based on whether the child has become mumayyiz or not, as previously discussed.

\section{Conclusion:-}

Islamic law does not prohibit the full acceptance of evidence from children. Eligible children are given the opportunity to express their views particularly in matters that directly involve their welfare such as the determination of custody. By asking for views and evidence from a child, does not mean that the judge will use the evidence singly. The judge is also not entirely bound by the evidence of the child. Instead, the evidence of the child involved can be a support to the main evidence for the court to make a decision. Through the court's discretion, a more accurate and justice decision may be achieved.

\section{Acknowledgement:-}

Acknowledgement to Universiti Kebangsaan Malaysia for funding this study under the Research University Grant, GUP-2016-065.

\section{References:-}

1. Abu Zahrah, Muhammad, al-Jarimah wa al- 'Uqubah, Dar al-Fikr al-Arabi, Kaherah, 1986. 
2. Adnan bin Muhammad bin Abd Aziz. Mausu'ah Huquq al-Insan fi al-Islam. Mu'assasah al-Risalah, Beirut, 1989.

3. Alwi Hj. Abdul Rahman. Jenayah Kanak-Kanak Menurut Undang-Undang Islam. Dewan Bahasa dan Pustaka, Kuala Lumpur, 1999.

4. Amin al-Jarumi. Pembuktian dalam Syariat Islam. Pusat Penerbitan Universiti (UPENA),Shah Alam, 2005.

5. Aminuddin Mustaffa, Siti Nurul Aziera Moharani. Isu Dan Permasalahan Keterangan Kanak-Kanak Di Bawah Undang-Undang Di Malaysia: Satu Penilaian. 24 Kanun (1): 52-76, 2012.

6. al-Faruqi, Harith Sulayman. Al-Mu'jam al-Qanuni. Maktabah Lubnan, Beirut, 1995.

7. Ibn Farhun. Tabsirat al-Hukkam fi Usul al-Aqdhiyyah wa Manahij al-Ahkam. Dar al-Kutub al-Ilmiyyah, Beirut, 2001.

8. Ibn Qayyim al-Jawziyyah. Al-Turuq al-Hukmiyyah Fi Siyasah al-Shar'iyyah. Mu'assasah al-'Arabiyyah, Kaherah, 1995.

9. Ibn Qudamah, Abu Muhammad Abdullah bin Ahmad bin Muhammad bin Qudamah. Al-Mughni al-Sharh alKabir, Vol. 6. Dar al-Kutub, Beirut, 1983.

10. Al-Kasani, Abu Bakr bin Mas’ud al-Kasani al-Hanafi. Bada'i al-Sana'i fi Tartib al-Shara'i, Vol. 5. Dar alKutub al-Ilmiyyah, Beirut, 1997.

11. Mahmud Saedon Awang Othman. Undang-Undang Keterangan Mahkamah Syariah: Satu Analisis. Dlm. Abdul Monir Yaacob (pnyt.). Undang-Undang Keterangan Dan Prosedur Mahkamah. Institut Kefahaman Islam Malaysia (IKIM), Kuala Lumpur, 1995.

12. Muhamad Abdul Karim Bin Wahab. Children's Participation in Sharia Court, Federal Territory Sharia Courts, 2015.

13. Roslina Che Soh. Children's Participation in Custody and Access Proceedings, IIUM Law Journal 22 (53), 2014.

14. Ruzman Md Noor. Pembuktian Di Mahkamah Syariah. Dalam. Dlm. Ahmad Hidayat Buang (pnyt.). UndangUndang Islam Di Malaysia: Prinsip Dan Amalan. Penerbit Universiti Malaya, Kuala Lumpur, 2007.

15. Ruzman Md. Noor. Kesaksian Dalam Konteks Undang-Undang Keterangan Mahkamah Syariah Di Malaysia: Analisis Dari Perspektif Mazhab Syafi'i. Jurnal Fiqh: No. 5, 2008.

16. Al-San'ani, al-Imam Muhammad bin Ismail al-Amir. Subul al-Salam Sharh Bulugh al-Muram min Jam'i Adillati al Ahkam. Dar al-Kutub al-'Ilmiyyah, Beirut, 2000.

17. Al- Shanqiti, Ahmad bin Ahmad al-Mukhtar al-Jukni al-Shanqiti. Mawahib al-Jalil min Adillah Khalil, Vol. 3. al-Maktabah al-'Ilmiyyah, Beirut, 2004.

18. Sharia Court Evidence (Federal Territory) Act 1997

19. Zanariah Noor. Aplikasi Prinsip Kebajikan Kanak-Kanak Dalam Kes Hadanah. Malaysian Journal of Syariah and Law, Vol. 2/2010, 2010. 